HoST - Journal of History of Science and Technology

Vol. 14, no. 2, December 2020, pp. 50-72

10.2478/host-2020-0014

\title{
Ludwik Fleck, Alfred Schutz, and Trust in Science: The Public Responsibility of Science Education in Challenging Times
}

\author{
Kathryn M. Olesko \\ Georgetown University \\ Kathryn.Olesko@georgetown.edu
}

\begin{abstract}
Ludwik Fleck and Alfred Schutz each wrote groundbreaking treatises in the 1930s that laid the foundation for their views on the role of science education in establishing trust in science. This essay examines how science education was for Fleck explicitly and for Schutz implicitly a crucial site for understanding the social dimensions of knowledge, for understanding how layers of knowledge are socially distributed among groups, and for conceptualizing how different cognitive groups, from experts to laypersons-communicate with one another in a democratic exchange of information. Their vision of the role of science education in establishing trust is particularly appropriate for addressing contemporary challenges to science and its results.
\end{abstract}

Keywords: Ludwik Fleck; Alfred Schutz; science education; trust in science 
The decade of the 1930s, known for some of the darkest days in Central Europe, was home to phenomenologist of society Alfred Schutz (1899-1959) and sociologist of knowledge Ludwik Fleck (1896-1961). Both wrote and published groundbreaking works during those years of turmoil: Schutz's The Phenomenology of the Social World appeared in 1932 and Fleck's Genesis and Development of a Scientific Fact in 1935. ${ }^{1}$ Much as they would have had something to say to each other, they probably never met. Decades later, after the untimely deaths of both authors, their books and the conceptual offshoots of them were recognized as powerful interpretations of how knowledge of reality, social for Schutz and scientific for Fleck, was constructed, understood, and communicated by specialists and laity alike.

Fleck, who dealt with scientific knowledge, is well known in the history of science. Schutz, concerned with social knowledge, is relatively unknown outside the circle of phenomenologists. At first glance they seem rather far apart in their concerns: Fleck with a social epistemology of science, and Schutz with a phenomenology of the social world. Except for a few of his essays from the 1940s, Schutz was not particularly concerned with natural scientific knowledge. Yet Schutz's later essays, which built on his 1932 exposé of the social world, suggest he and Fleck shared similar approaches to how scientific knowledge operated in the everyday world that are worth examining comparatively. ${ }^{2}$ Both studied knowledge in the context of social worlds: how belief in knowledge was sustained by intersubjective communication (communication between two or more persons); how interlocutors themselves are transformed through knowledge acquisition; and most importantly, how communication cultivated trust, especially in scientific results (both natural and social), thus fostering respect and social cohesion. Science education was, for Fleck explicitly and for Schutz implicitly, a crucial site for understanding the social dimensions of knowledge, for understanding how layers of knowledge are socially distributed among groups, and for conceptualizing how different cognitive groups—specialists or experts, rank-and-file scientists, well-informed citizens, and laypersons-communicate with one another in a democratic exchange of information.

This essay examines how the contributions of Fleck and Schutz to the sociology of knowledge, a relatively new intellectual field that began to flourish in the late 1920s, offer a conceptual framework for understanding how science education, among all forms of scientific communication, curates and mediates the lay public's engagement with science and

\footnotetext{
${ }^{1}$ Alfred Schutz, The Phenomenology of the Social World (Chicago: Northwestern University Press, 1967), originally published as Der sinnhafte Aufbau der sozialen Welt: Eine Einleitung in die verstehende Soziologie (Vienna: Springer, 1932); Ludwik Fleck, Genesis and Development of a Scientific Fact (Chicago: University of Chicago Press, 1979), originally published as Entstehung und Entwicklung einer wissenschaftlichen Tatsache: Einführung in die Lehre vom Denkstil und Denkkollektiv (Basel: Schwabe, 1935).

2 Alfred Schutz, "The Problem of Rationality in the Social World," Economica 10 (1943): 130-49; Alfred Schutz, "The Well-Informed Citizen: An Essay on the Social Distribution of Knowledge," Social Research 13, no. 4 (1946): 463-78.
} 
their perceptions of it, thereby fostering trust of science. It begins with Fleck's and Schutz's encounter with issues concerning education in the natural and social sciences during the 1920s. It then examines how each viewed science education and the production of expertise, highlighting their views on how confidence and trust in the results of science are achieved during challenging times. Finally, this essay reflects on how the works of Fleck and Schutz suggest an approach to the historical study of science education that is particularly appropriate for addressing contemporary challenges to science and its results.

Trust in science is not necessarily a given, especially during the 1920s and 1930s when knowledge was regarded with suspicion in Central Europe. As the German orientalist Carl Heinrich Becker noted in his 1930 commentary on "the cultural crisis of the present," the possession of knowledge was stigmatized as a sign of the lack of education. ${ }^{3}$ That observation runs counter to the intensely creative activity in the natural and social sciences during the 1920s in which Fleck and Schutz were immersed. Schutz absorbed and critiqued Max Weber's sociology, Henri Bergson's philosophy, and Edmund Husserl's phenomenology. Fleck was impacted by an intellectual climate that was infused with irrational onslaughts against science, most stemming from quantum theory's questioning of classical physics. Despite Becker's claim that the possession of knowledge was a stigma, Fleck and Schutz both believed that the public had a role to play in engaging scientific knowledge and in offering a perspective on it. For both, intersubjective communication between groups possessing different degrees of engagement with natural scientific knowledge - the most basic being between experts and laity-was crucial for securing trust in science and its results.

Science education, including science popularization, was the key institutional site for creating conditions conducive to this kind of intersubjective communication. Sociology of knowledge, as constructed by Fleck and Schutz, emphasized that science education could and should convey how science operated, including in the public sphere. But their conception of how scientific knowledge was created went beyond theoretical formulations and experimentation to include the ebb and flow of exchanges between experts and laypersons. Their understanding of science education is pertinent to today's environment where feckless leadership, especially in the United States, has eroded trust in science and scientists. A journey back to the intellectual creativity of the 1930s - historically well-established as a reaction to the "irrational" climate of the 1920s_-suggests that reinvigorating this social and civic responsibility of science education to cultivate trust can help to counteract the baseless criticisms and destructive ignorance of scientific and medical knowledge today.

\footnotetext{
${ }^{3}$ Carl Heinrich Becker, Das Problem der Bildung in der Kulturkrise der Gegenwart (Leipzig: Quelle \& Meyer, 1930), 21-22.
} 


\section{Emerging from the "Irrational" 1920s}

The impact of the transformative intellectual trends of the 1920s - the cultural endorsement of acausality, the rebuke of materialism and determinism, the drift toward irrationality, and the epistemological questioning of an objective reality-is well established in the history of science literature. ${ }^{4}$ Fleck associated these developments with the social turmoil following the Great War, which spawned dissenting views and fractious rivalries where there had been consensus, cognitive confusion where there had been clarity, and the disintegration of symbols which had formerly conveyed unambiguous meaning. ${ }^{5}$ The intellectual ferment of the 1920 s grew at a frenetic pace across the decade, targeting in particular western civilization and its hollowedout values and laying blame not only on the Great War, but also on science and technology. ${ }^{6}$ The crisis state of the sciences in particular motivated philosopher Edmund Husserl to address the issue in 1936, in a work that became his most famous. ${ }^{7}$ Even something as commonplace and ordinary as narrative eroded: Virginia Woolf's To the Lighthouse was a novel anti-novel that used an inverted narrative structure as a trope for characterizing the inhuman war that had turned everything upside down, while French historians, soon to be known as the Annales school, laid the foundation for a social and economic history that disrupted the flow of narrative with new conceptions of historical space and time. ${ }^{8}$ Sigmund Freud's Civilization and Its Discontents capped the decade with the observation that science and technology were cheap thrills, and with the proposition that civilizations, like individuals, can become neurotic. ${ }^{9}$ The ideas, symbols, tropes, and conceptual structures that had earlier held intellectual life together crumbled in the 1920s. No wonder the decade witnessed the emergence of the first sustained forays into the sociology of knowledge, most notably by Karl Mannheim, a contemporary but not an interlocutor of Fleck or Schutz. ${ }^{10}$

\footnotetext{
${ }^{4}$ Paul Forman, "Weimar Culture, Causality, and Quantum Theory, 1918-1927: Adaptation by German Physicists and Mathematicians to a Hostile Intellectual Milieu," Historical Studies in the Physical Sciences 3 (1971): 1-115. The controversial nature of the "Forman thesis" has spawned numerous commentaries, most recently in Cathryn Carson, Alexei Kojevnikov, and Helmuth Trischler, eds., Weimar Culture and Quantum Mechanics: Selected Papers by Paul Forman and Contemporary Perspectives on the Forman Thesis (London: Imperial College Press and Singapore: World Scientific Publishing, 2011).

${ }^{5}$ Fleck, Genesis and Development, 177-78.

${ }^{6}$ Oswald Spengler, The Decline of the West, 2 vols. (New York: Knopf, [1918, 1922] 1932).

7 Edmund Husserl, The Crisis of European Sciences and Transcendental Phenomenology (Evanston, Ill.: Northwestern University Press, [1936] 1970), esp. 3-18.

${ }^{8}$ Virginia Woolf, To the Lighthouse (New York: Harcourt, 1927); Peter Burke, The French Historical Revolution: The Annales School 1929-89 (Stanford: Stanford University Press, 1990).

${ }^{9}$ Sigmund Freud, Civilization and its Discontents (New York: Norton, [1930] 1962), 34-35.

${ }^{10}$ Karl Mannheim, Essays on the Sociology of Knowledge (London: Routledge, 1952), esp. 134-90 ("The Problem of the Sociology of Knowledge [1924]").
} 
Fleck and Schutz were both immersed in the epistemological controversies that marked the 1920s, but from opposite ends of the intellectual spectrum: Fleck, from the perspective of the natural sciences, and Schutz, from the social sciences. Born in 1896, in the multiethnic and liberal intellectual city of Lemberg, Galicia in the eastern section of the Austro-Hungarian Empire, Fleck — who had already begun his medical studies at the University of Lembergentered the Great War as a medic working with the zoologist-turned-immunologist Rudolf Weigl. When he returned home in 1919, Fleck joined Weigl's serological laboratory at the University of Lwów (Lemberg had become Lwów, Poland after the war) where he received his medical degree in 1922. Between 1923 and 1935, when he was forcibly removed from his position because he was Jewish, Fleck worked as a clinical microbiologist in serology, immunology, and bacteriology in the Lwów General Hospital, including a two-year stint, from 1925 to 1927 , working at a state serotherapeutic institute in Vienna. While in Vienna he attended Freud's lectures, visited Paris to hear talks by the philosopher Henri Bergson, and learned about the Vienna Circle of logical positivists, which convened under the philosopher Moritz Schlick. Fleck later condemned the Vienna Circle's "excessive respect for logic" and for "regarding logical conclusions with a kind of pious reverence."11 After Lwów was occupied in 1941, Fleck lived and worked in the Jewish ghetto before being sent to Auschwitz in 1943 and then to Buchenwald later that year, where he was incarcerated until 1945. He died in 1961 of Hodgkin's disease. ${ }^{12}$

Whether or not the Viennese and Parisian trips had an impact on Fleck beyond the rejection of logical positivism is unknown. It certainly does not appear to be coincidental, however, that in 1927 Fleck delivered a lecture at the Lwów Society for the History of Medicine that compared medical and scientific epistemologies, specifically on the uncertainty in identifying illnesses, which had ranges of symptoms, with the greater certainty possible in the natural sciences, where variations were less frequent. Fleck cast the difference, perhaps too strongly, in terms of the relative "irrationality" of illness and disease identification in comparison to the rationality of the natural world, a distinction he made somewhat clearer by likening medical symptoms to Gaussian distributions and natural events to Cartesian coordinate systems. Even so, the statistical regularities in medicine, which he further identified as ideal clinical types, did not, in his view, create "the fundamental concepts of our knowledge." Medical thinking, in his view, was "not logical" and therefore not positivistic, but instead required a "specific

\footnotetext{
${ }^{11}$ Fleck, Genesis and Development, 50.

12 Thaddeus J. Trenn, "Biographical Sketch,” in Fleck, Genesis and Development, 149-53; Thomas Schnelle, "Microbiology and Philosophy of Science, Lwów and the German Holocaust: Stations of Life Ludwik Fleck 1896-1961," in Cognition and Fact: Materials on Ludwik Fleck, eds. Robert S. Cohen and Thomas Schnelle, 3-36 (Dordrecht: Reidel, 1985); Claus Zittel, "Ludwik Fleck and the Concept of Style in the Natural Sciences," Studies in Eastern European Thought 64 (2012): 53-79; Arthur Allen, The Fantastic Laboratory of Dr. Weigl: How Two Brave Scientists Battled Typhus and Sabotaged the Nazis (New York: Norton, 2014), esp. 1-78.
} 
intuition" for foreseeing "the course of problems which determine the development of a given field of thought and create a style peculiar to the epoch." He was not able to specify what this "specific intuition" was except by contrast to "book knowledge," a clear reference to the context of learning medical theory where a certain "fictitiousness" existed in the form of succinct definitions that overlooked variations visible in direct observations of illnesses. This "specific intuition" required the medical observer "to alter the angle of vision, and to retreat from a consistent mental attitude" - in short, to place book knowledge, which could not be completely trusted when assessing actual cases in the real world, in perspective. ${ }^{13}$ Thus, central to his analysis was not only an acknowledgment of the limitations of the types of knowledge conveyed through book-based education, but also of the permissibility and necessity of viewing disease and illness from outside the box.

Shortly after this essay, two developments in 1928 provided additional evidence for the role of flexible modes of perception in scientific observation and the necessary but constraining role of education in medical thinking. Early in the year he encountered Niels Bohr's famous Como lecture, delivered in September 1927 and published simultaneously in German and English in mid-April $1928 .{ }^{14}$ Centered on the quantum postulate - the idea that at the atomic level there are discontinuities foreign to classical physics forcing a renunciation of classical spacetime as well as the idea that observation is independent of the means of measurement-Bohr's lecture developed the notion of complementarity, the idea that, at the atomic level, there are pairs of qualities or properties that could not be measured simultaneously in contrast to the macroscopic level of classical physics where they could be. Bohr's article brought Fleck face to face with the process of conceptual change in the sciences. Four issues were paramount: between competing systems of symbols; between alternative modes of observation and the role of sense perception in them; between different conceptions of how measurement occurred; and, finally, between different interpretations of reality.

Important for Fleck's later understanding of perception in science was Bohr's renunciation of "visualization in the ordinary sense" in favor of "adapting our modes of perception borrowed from the sensations to the gradually deepening knowledge of Nature." 15 Related to the role of perceptual adaptation in recognizing another level of reality was the equivocal nature of measurement in quantum theory, which rendered classical concepts like velocity ambiguous and where the instrumental means of observation could not be separated from observational results. When Bohr mentioned Werner von Heisenberg's analogy between quantum and

${ }_{13}$ Ludwik Fleck, "Some Specific Features of the Medical Way of Thinking [1927]," in Cohen and Schnelle, Cognition and Fact, 39-46, on 40, 43. Fleck's ideal types appear not to be Max Weber's.

${ }^{14}$ Niels Bohr, "Das Quantenpostulat and die neuere Entwicklung der Atomistik," Die Naturwissenschaften 16 (1928); 245-57; Niels Bohr, "The Quantum Postulate and the Recent Development of Atomic Theory," Nature 121 (1928): 580-90.

15 Bohr, "The Quantum Postulate," 584, 586. 
classical uncertainty in measurement, he highlighted the alternative reality-creating functions of measurement in each realm. In classical physics repeated measurements, though "imperfect," defined macroscopic phenomena and predicted future events "with ever-increasing accuracy." But, in quantum theory, "every observation introduces a new uncontrollable element" that disturbs the interpretation of reality. ${ }^{16}$ This duality, with its seemingly incommensurable alternatives, made a lasting impression on Fleck.

A second intellectual development in 1928, lasting from July through December, confronted Fleck with how different groups in the same discipline, this time in medicine, were unable to communicate with one another when they came from different traditions in pre-clinical instruction. ${ }^{17}$ This pedagogical controversy began July 1928 with some "critical considerations" of the pre-clinical curriculum by Albrecht Bethe, a physiologist and physician at the University of Frankfurt. ${ }^{18}$ Bethe, a specialist in nerve physiology, resurrected the long-standing debate over whether anatomy or physiology should be the scientific foundation of medical instruction. At this time the controversy was not only one of structure versus function, of a morphological way of thinking versus a functional one, but also of what role the basic sciences of chemistry and physics should have in medical instruction.

Bethe objected to what he viewed as the dead weight of anatomical knowledge in pre-clinical instruction, with its misguided ways of transforming students into physicians. Overemphasizing anatomy, he argued, suffocated students with too much detail; sidelined recent developments in physiology, chemistry, and physics that were of greater relevance to medical practice; and led to meaningless rote learning that failed to distinguish what was Wissenswerte (trivia) from what was Wissensnotwendig (necessary to know). Anatomical instruction, he complained, wrongly replaced the "bare eye" with the "weaponized eye," a transformation that was overcultivated by the relentless pursuit of accuracy in the preparation of anatomical slides from dissections, a skill more useful for scientists than physicians. Physiology, with a solid chemical and physical foundation, he thought, had greater relevance for the medical profession, especially because it, not anatomy, was a vibrant research field producing exciting new results. In a final blow to traditionalists, he charged that current anatomical instruction "belongs to the time of our grandfathers" and that if greater anatomical knowledge was necessary, a textbook could simply be consulted. ${ }^{19}$

\footnotetext{
${ }^{16}$ Ibid., 582, 584, 585.

${ }_{17}$ Fleck, Genesis and Development, 36, 173.

${ }_{18}$ Albrecht Bethe, "Kritische Betrachtungen über den vorklinischen Unterricht," Klinische Wochenschrift 7, no. 31 (1928): 1481-83. Albrecht Bethe was the father of atomic physicist Hans Bethe, who in July 1928 had just received his doctorate from the University of Munich, where he had studied under Arnold Sommerfeld, a prolific mentor of atomic physicists.

${ }^{19}$ Ibid., 1482.
} 
His criticisms riled those in the anatomical tradition. Of the six responses to Bethe's missive, only one-from Ernst Göppert, Director of the Anatomical Museum at the University of Marburg-agreed with him, although not completely. ${ }^{20}$ The other five defended anatomy as the foundation of pre-clinical instruction, which had implications for how the senses were trained as well as for the conceptual orientation of the physician. ${ }^{21}$ The views of Hans Petersen, anatomist at the University of Würzburg, exemplify the nature of the criticisms leveled against Bethe. Petersen himself was sympathetic to taking both a functional and structural view of anatomy, but observed that the same criticisms leveled against anatomical instruction applied equally well to physiological instruction where boring details and senseless questions on examinations were to be found. His critique of Bethe was guided by visual images: of anatomy as the "cellar floor" of the building called medicine; of the "Anschaulichkeit" or perceptual vividness of anatomy; and of the sense in which anatomy provided the learner with a meaningful context (Sinnzusammenhang) for understanding the body. Claiming that slide preparations made from slices of body parts could substitute for actual anatomical parts, he observed, would be like arguing that pictures of a trip could substitute for a trip. ${ }^{22}$ Conceptually and visually the anatomists lived, viewed, and taught from a perspective different from Bethe. "Our viewpoints are different!" Bethe concluded at the end of the exchange, noting that on each side of the controversy there were persons of "entirely different structures of thinking." ${ }^{23}$ This exchange over medical pedagogy provided Fleck with concrete evidence of what he later identified as a thought style, including the impossibility of "direct communication between adherents of different thought styles." ${ }^{24}$

Schutz's immersion in the critique of the social sciences in the 1920s, when questions were raised as to whether or not the social sciences deserved to be called "science" in the same sense as the natural sciences, paralleled Fleck's engagement with crises in the natural sciences. A native of Vienna, Schutz fought in the Austrian Army in the Great War before entering the University of Vienna to study international law, the field of his doctorate in 1921. While at the university he interacted with an influential group of economists in the classical liberal tradition gathered in Ludwig von Mises's seminar, including Friedrich von Hayek and Oskar

${ }^{20}$ Ernst Göppert, "Kritische Betrachtungen über den vorklinischen Unterricht," Klinische Wochenschrift 7, no. 39 (1928): 1876.

${ }^{21}$ Hans Petersen, "Über die Rolle der Anatomie im Lehrgang des künftigen Arztes," Klinische Wochenschrift 7, no. 39 (1928): 1872-75; Rudolf Fick, "Betrachtungen über den vorklinischen Unterricht," Klinische Wochenschrift 7, no. 40 (1928): 1921-23; Friedrich W. Fröhlich, "Über den vorklinischen Unterricht," Klinische Wochenschrift 7, no. 40 (1928): 1923-24; Kurt Goldstein, "Betrachtungen über den vorklinischen Unterricht," Klinische Wochenschrift 7, no. 50 (1928): 2399-2402; Dankwart Ackermann, "Bemerkungen zu dem Aufsatz von Fröhlich," Klinische Wochenschrift 7, no. 50 (1928): 2402.

22 Petersen, "Rolle der Anatomie."

${ }^{23}$ Albrecht Bethe, "Form und Geschehen im Denken des heutigen Arztes," Klinische Wochenschrift 7, no. 50 (1928): 2402-5, on 2402, 2403.

${ }^{24}$ Fleck, Genesis and Development, 36. 
Morgenstern, but challenged their assumptions concerning the rational foundation of human behavior. Similarly, he questioned the positivistic stance of the Vienna Circle, arguing that pre-scientific experiences were formative for later, more abstract forms of understanding. In 1927 he began to work for Reitler \& Co., an international banking firm that he left in 1938 due to the persecution of Jews in Europe. He journeyed first to France, where he met Maurice Merleau-Ponty and Raymond Aron, and then in 1939 emigrated to New York City where lived a dual life as a banker and a phenomenological sociologist. Offered an affiliation at the New School for Social Research in 1943, Schutz delved into the pragmatic philosophies of John Dewey and Henry James and formed a life-long intellectual friendship with the sociologist Talcott Parsons. In 1952 he was appointed professor at the New School. ${ }^{25}$ He died in 1959, two years before Fleck.

During the 1920s Schutz immersed himself in the work of Max Weber, whose lectures he had heard at the University of Vienna, where Weber taught briefly before dying from pneumonia, a consequence of Spanish flu, in 1920. Enamored with Weber's interpretive sociology (the Verstehen approach), Schutz sought to develop it further by undergirding it with deeper epistemological considerations, especially by explaining how the meaning of social action could be conceptualized, especially in intersubjective communication. From Weber, Schutz understood that reality was not one, but made up of layers coalesced around value orientations; culture itself was a value-concept. For Weber, the study of social reality entailed the use of heuristic devices or mental constructs (Gedankenbilder) like ideal types, which were not real but served as a means of determining, through comparison with reality, the degree to which reality diverged from an ideal type. ${ }^{26}$ Weber's relative lack of attention to the problem of meaning led Schutz to consider whether or not Henri Bergson's discussion of the relationship between temporality and consciousness might be used to understand how actors created and understood meaning. Finding Bergson's ideas inadequate, however, Schutz turned to the work of Edmund Husserl instead, using Husserl's concept of the life-world, the world of daily experience or the pre-scientific world, as a starting point for the construction of meaning through intersubjective exchanges. By 1932, when Schutz published The Phenomenology of the Social World,

${ }^{25}$ Jochen Dreher, "Alfred Schutz," in Classical Social Theorists, eds. George Ritzer and Jeffrey Stepnisky, 489-510, vol. 1 of The Wiley-Blackwell Companion to Major Social Theorists (Malden, Mass.: WileyBlackwell, 2011); Søren Overgaard and Dan Zahavi, "Phenomenological Sociology: The Subjectivity of Everyday Life," in Encountering the Everyday: An Introduction to the Sociologies of the Unnoticed, ed. Michael Hviid Jacobsen, 93-115 (Hampshire, U.K. and New York: Palgrave Macmillan, 2009); Michael Barber, The Participatory Citizen: A Biography of Alfred Schutz (Albany, N.Y.: State University of New York Press, 2004); Michael Barber, "Alfred Schutz," The Stanford Encyclopedia of Philosophy (Summer 2020 Edition), ed. Edward N. Zalta, https://plato.stanford.edu/archives/sum2020/entries/schutz/, accessed September 27, 2020.

${ }^{26}$ Max Weber, "Objectivity' in Social Science and Social Policy [1904]," in The Methodology of the Social Sciences, eds. Edward A. Shils and Henry A. Finch, 49-113 (Glencoe, Ill.: Free Press, 1949). Weber's famous definition of ideal types is found in this essay (90). 
he had spent twelve years studying Weber, focusing primarily on how meaning was constructed in the course of social action. ${ }^{27}$

Schutz's style, unlike Weber's, was largely philosophical and bereft of empirical examples. When Schutz did refer to specific cases in his early work from the 1920s (almost all remained unpublished until after his death), he drew upon examples from music, art, drama, opera, language, and literature, not from the natural sciences. ${ }^{28}$ In the course of his study of Weber, though, he could not have avoided learning about educational issues in the social sciences that paralleled those Fleck had encountered in medicine and the physical sciences. Laced throughout Weber's writings were remarks about the nature of instruction, the posture of the instructor, and the responsibilities of students, including their obligation to learn how to make their own judgements. Weber observed that the methodological diversity of the social sciences, which had created a "patchwork of cultural values," along with Germany's political situation during the Great War, had aroused student interest in a type of academic leadership that would convey subjective value orientations as well as objective disciplinary instruction. ${ }^{29}$ Yet, he was firmly against that ever happening in "the secret chamber of the lecture hall," where, in his view, there should be a strict separation of fact and value. ${ }^{30}$ In the lecture hall, the appropriate topics of discussion were facts, causal connections, and the logical state of affairs. These elements were the ones that made communication with others possible: for "the common ground we share with our opponents is the straightforward science of facts." ${ }^{31}$ The lecture hall was separate from the public sphere; the lecture was not a public speech. Indeed, the quality of the lecture declined, Weber admonished, if it acquired the "style of the press." 32

Weber thus depicted education in the social sciences as the site of a struggle between fact and value, of which students had to become cognizant and learn how to navigate, even when their professors slipped and revealed value judgements in the classroom. In cases where professors did not exercise restraint, an unspoken code protected them. Citing the economist Gustav von Schmoller's successful legal prosecution of a student who made public the political statements Schmoller had uttered in the lecture hall, Weber identified an academic norm that barred

${ }^{27}$ Dreher, "Alfred Schutz"; Overgaard and Zahavi, "Phenomenological Sociology."

${ }^{28}$ Alfred Schutz, Life Forms and Meaning Structure (London/New York: Routledge, 2014).

${ }_{29}$ Max Weber, "The Meaning of Ethical Neutrality in Sociology and Economics [1917]," in Shils and Finch, Methodology of the Social Sciences, 1-47, on 4.

${ }^{30}$ Max Weber, "Academic Freedom at Universities [1909]," in Max Weber's Complete Writings on Academic and Political Vocations, ed. John Dreijmanis, 69-74 (New York: Algora, 2008), 70.

${ }^{31}$ Max Weber, "Transactions of the Third German Conference of Teachers in Institutions of Higher Learning [1909]," in Dreijmanis, Complete Writings on Academic and Political Vocations, 75-77, on 76.

32 Weber, "Ethical Neutrality," 4. 
professorial pronouncements from leaking into the public sphere. ${ }^{33}$ Rather than invoking value judgements, the true teacher, Weber argued, should undertake the "primary task" of teaching "students to recognize 'inconvenient' facts." ${ }^{34}$ Just as the teacher was supposed to don the mask of a particular persona, so too would the student, whose responsibility it was to acquire intellectual integrity, clarity in thinking, and the capability to make one's own decisions. Because the university's task was to teach students how to think and not to preselect what gods to serve, students had to learn how to separate fact and value, even in cases where the professor was "temperamentally prevented" from doing so. ${ }^{35}$ Acquiring knowledge thus not only changed the student into someone who was learned (and perhaps even into an expert), but also into someone who was capable of discriminating objective results from valueorientations. ${ }^{36}$ In a famous set of essays from 1918, "Science as a Vocation" and "Politics as a Vocation," Weber embedded the distinction between fact and value in the historical processes of rationalization and intellectualization. The unfolding of these two narratives led, in his view, to the disenchantment of the world where cold calculations replaced mysterious forces. ${ }^{37} \mathrm{By}$ further separating science- by which he meant the Wissenschaften, or all scholarship and not just the natural sciences-from politics, these two essays added to his view of education as a realm devoid of politics, value judgements, and discussions concerning the meaning of the world.

Whether in the form of Bethe's objection to the emphasis on anatomy in pre-clinical instruction or of Weber's insistence on students learning how to separate fact from value judgements, the knowledge crises of the 1920s conspicuously singled out education as a site of active epistemological discrimination where both teachers and students engaged critically in the assessment of knowledge claims. While Schutz did not at this time comment on Weber's perspective on education, the fact-value distinction surely played a role in his decision to focus on the role of meaning in social action, a relationship Weber had left underdeveloped. Fleck, by contrast, recognized that the fictions created by book knowledge had to be placed in perspective in order to make assessments, which in any event were hindered by an immersion in particular ways of thinking that made intersubjective communication near impossible, as the debate over Bethe's efforts to make physiology rather than anatomy the foundation of preclinical instruction in medicine illustrated.

33 Weber, "Academic Freedom," 69-70.

${ }^{34}$ Max Weber, "Science as a Vocation," in From Max Weber: Essays in Sociology, eds. H. H. Gerth and C. Wright Mills, 129-56 (New York: Oxford University Press, 1946), 147.

35 Weber, "Academic Freedom," 70; Weber, "Ethical Neutrality," 2; Weber, "Science as a Vocation," $150-51$.

${ }^{36}$ Weber, "Ethical Neutrality," 4

${ }^{37}$ Weber, "Science as a Vocation;" Max Weber, "Politics as a Vocation," in Gerth and Mills, From Max Weber, 77-128. 


\section{Fleck: The Public Function of Science Education}

As the decade of the 1920s drew to a close, Fleck pondered the epistemological challenges posed by quantum theory as rendered in Bohr's Como lecture and by the 1928 debate over preclinical instruction. His Genesis and Development of a Scientific Fact, completed in 1933 and published in 1935, is customarily viewed as a forgotten harbinger of a social constructionist view of scientific knowledge. "Cognition is the most socially-conditioned activity of man, and knowledge is the paramount creation," he wrote. ${ }^{38}$ The book's title neatly encapsulates its thesis: facts don't wait to be discovered in objective reality, they come into being through a cognitive process that drags along vestiges of history and tradition, pays homage to the everyday world of common sense, and that, for the most part, makes sure that they fit into an ongoing framework for thinking in a particular field. Fleck developed two key concepts for his sociological analysis of scientific knowledge: the thought collective, or "community of persons mutually exchanging ideas or maintaining intellectual interaction;" and the thought style, or habits of thinking sustained by intersubjective communication and social forces. These habits minimized caprice in thinking, directed perception, and tended to reinforce the intellectual status quo, but were open to shifts based on new developments, as had occurred in physics with relativity and quantum theory. A scientific fact could only exist within a thought style: it is "a thoughtstylized relation" that "represents a stylized signal resistance in thinking." ${ }^{39}$ Collectively, facts create a fixed reality. Truth, in Fleck's way of looking at science, is a stylized thought constraint.

Fleck assigned science education a central role in the maintenance of a thought style and a thought collective, placing special emphasis on the act of learning and "special methods of teaching." He devoted most of his attention to the education of specialists and rank-and-file scientists. He cast learning in religious terms, calling it a "rite of initiation" wherein "the Holy Ghost as it were descends upon the novice, who will now be able to see what has hitherto been invisible to him." ${ }^{40}$ Textbooks, ubiquitous in science education, were evidence, in Fleck's mind, of the existence of thought collectives. His most thoroughly developed example came, unsurprisingly, from an anatomical textbook, with its vivid, illustrative, and emotive images. ${ }^{41}$ Science's links to the past were preserved in concepts, accepted problems, and "the syllabus of formal education.. ${ }^{42}$ Education and tradition produced a "readiness" for stylized thinking. ${ }^{43}$ Yet, the written word only worked to a point in science education. Skills of observation, the ability

\footnotetext{
${ }^{38}$ Fleck, Genesis and Development, 42.

${ }^{39}$ Ibid., 95, 98.

${ }^{40}$ Ludwik Fleck, "On the Crisis of 'Reality' [1929]," in Cohen and Schnelle, Cognition and Fact, 47-57; Fleck, Genesis and Development, 104.

${ }^{41}$ Fleck, Genesis and Development, 133-45, but see also 55-59; Ludwik Fleck, "Scientific Observation and Perception in General [1935]," in Cohen and Schnelle, Cognition and Fact, 59-78, on 66-71.

${ }^{42}$ Fleck, Genesis and Development, 20.

43 Ibid., 84.
} 
to think scientifically, and a knack for problem solving could not be taught by formal logic or through verbal formulas, but only through experience. ${ }^{44} \mathrm{~A}$ prominent example throughout his works, one that harks back to Bohr's Como lecture, was the act of measuring and weighing, which required foreknowledge of what results would look like and a "readiness to see certain forms." ${ }^{\prime 5}$ Finally, education altered the self, especially the senses. The imprint of social factors is found in the process by which students learn what they see. But there were limitations: instruction informed by a particular thought style trained vision to see some forms but not others. ${ }^{46}$ There were no style-less observations. A higher level of training led to the ability to discern, rather than merely learn, which involved freeing oneself from the dogmatic elements of instruction. ${ }^{47}$

The specialist was only one element in Fleck's depiction of how science operated. Fleck drew concentric esoteric and exoteric circles of knowledge, which demarcated domains of participation in the scientific enterprise, broadly conceived. In these were found the communication channels for achieving trust in science. Moving outward from the esoteric circle at the center where specialists or experts worked, there were found, in this order, rankand-file scientists, educated persons, and then, at the outmost fringes of the exoteric circle, educated amateurs, laypersons, and the general public. Any individual occupied more than one location: a person could be a specialist in one area, but a layperson in all others. Each group corresponded to a different form of scientific knowledge, with journal science occupying the esoteric center, changing to vademecum or handbook science, then textbook science, and finally at the exoteric periphery, popular science and commonsense knowledge. Significantly for Fleck, though, knowledge also moved in the opposite direction: vestiges of popular science and commonsense knowledge were often found in specialist knowledge. The movement of knowledge back and forth between groups promoted trust and community cohesion. ${ }^{48}$

Trusting science was, thus, the result of a dynamic social process for Fleck, a process that entailed interaction between center and the periphery. Communication occurred back and forth across these domains. Scientific elites at the center were dependent upon the public and upon popular science for legitimation, and so had to strive for the trust of the masses. For Fleck the public had a special responsibility to sustain trust in science. While elites had to acknowledge the role of the public in recognizing the legitimacy of science, the public had an obligation to discuss

${ }^{44}$ Ibid., 10; Fleck, "Scientific Observation," 60.

${ }^{45}$ Ludwik Fleck, "To Look, To See, To Know [1947]," in Cohen and Schnelle, Cognition and Fact, 12952, on 142 and 147 (Bohr), 144 (quote), 145 (example of how foreknowledge affects the expectation of measurement result). Also see Fleck, "Crisis of 'Reality'," 51-53; and Fleck, "Scientific Observation," 64-65, 77.

${ }^{46}$ Fleck, "Crisis of 'Reality'," 48; Fleck, "Scientific Observation," 60.

${ }^{47}$ Fleck, Genesis and Development, 96.

${ }^{48}$ Ibid., 102, 105, 112, 118-19. 
and disseminate scientific truth. When the public was strong, a democratic tendency and dynamic balance prevailed in the esoteric and exoteric circles. Scientific elites acknowledged public opinion and cultivated the confidence of the public, while the public, in turn, trusted specialists without overestimating or underestimating their limitations. When the public was weak, however, imbalances in the form of totalitarian tendencies could emerge. The public could become docile or succumb to blind obedience to authority, with the consequence that elites then became isolated and trust in science waned. For Fleck a strong public approbation of and engagement with science were essential for the scientific enterprise to be effective. Simply put, a strong interactive dependency between scientific elites and the public was essential for sustaining trust in science. ${ }^{49}$

It is on this issue-public engagement with science-that Fleck's focus on science education takes on added significance. While a core of his argument concerning how facts emerge focused on the education of the specialist, in particular how the specialist was transformed in the process of learning, the education of the public was just as essential for cultivating trust in science. Here, Fleck divided the knowledge field into three parts: general scientific education, popular science, and commonsense knowledge. Commonsense was the "personification of the thought style of everyday life" that could and did on occasion move in the direction of a scientific style, as the everyday distinction between "hot" and "cold" became a temperature reading with the invention of the thermometer. ${ }^{50}$ Popular science in Fleck's view, if properly formed from specialist knowledge, was simple, vivid, lucid, certain, and emotive. It both formed the background for specialized knowledge by creating a worldview and informed public opinion. If not properly constructed, however, popular science could turn into propaganda, which led to distrust of scientists and their results. ${ }^{51}$ The third form of knowledge in public education, general scientific education, functioned as the crossroads between popular science and commonsense knowledge, on the one hand, and specialist knowledge, on the other. Fleck framed general scientific education in religious terms, as the "sacrament of initiation" for recruiting future specialists who, so long as they were in the generalist stage, had the status of apprentices who learned the "mood of the collective." 52 With his emphasis on the emotive dimensions of instruction, Fleck distanced this general scientific education from a rationalist pedagogy (which he, in any event, thought was impossible), yet admitted that general scientific education was an authoritarian introduction to the principles of a thought style. ${ }^{53}$ Education in all of its forms, whether of the specialist, generalist, or layperson, brought each group in

49 Ibid., 105-6, 124; Ludwik Fleck, "The Problem of Epistemology [1936]," in Cohen and Schnelle, Cognition and Fact, 79-112, on 88, 102, 103, 105.

${ }^{50}$ Fleck, "Problem of Epistemology," 107.

${ }^{51}$ Fleck, Genesis and Development, 112-17.

52 Fleck, "Problem of Epistemology," 100, 101, 106.

53 Ibid., 106. 
contact, curated appropriate scientific knowledge for each group, and provided the framework for the democratic exchange of knowledge between each of them.

In 1927, Fleck wrote that "natural science is the art of shaping a democratic reality and being directed by it - thus being reshaped by it." ${ }^{54}$ Nearly a decade later he identified the "problem of epistemology" as the circulation and communication of scientific knowledge, with special attention to the role of the public in sustaining trust in science. Thus, in his view a thought collective was not something socially isolated that included among its members only specialists: a thought collective by its very nature required engagement with the public. The public can thus be viewed as a locus where thought collectives, propelled by social forces like public opinion, bumped up against one another to create what Fleck called a "creative chaos." Communication among thought collectives, or between thought collectives and the public, was fraught with dangers: translations of terms into another collective's discursive practice could produce misleading simplifications or even propaganda, while taking a collective's statements out of context could produce what Fleck called "artificial gardens," collections of ideas that lacked an environment for growth. ${ }^{55}$ His point was that thought collectives, while they could produce noise that disrupted communication when interacting with each other, were nonetheless dynamic entities that necessitated public engagement.

For the most part Fleck's analysis of science education and the role of the public in shoring up trust in science made little reference to the world in which he lived. In 1935, however, he reflected back on the changes physics had endured in the 1920s, noting that physics, which could not protect itself from outside influences while undergoing profound changes, offered an instructive example for medicine. ${ }^{56}$ Later, after the end of the Second World War, the defeat of fascism, and his own liberation from Buchenwald, Fleck could no longer avoid commenting on threatening circumstances that distorted communication between, and skewed judgements within, the esoteric and exoteric spheres, thereby diminishing trust in science. A few examples will suffice. First, inadequate training, as occurred in the infamous Buchenwald anti-typhus vaccine thought collective composed of laypersons and non-specialists who had relied on specialist literature without being trained in it, led in Fleck's view to the "collective illusion" that their results were correct—and hence could be trusted — even in the face of contradictory findings from a scientific institute. ${ }^{57}$ Second, developments during the interwar period and the

\footnotetext{
${ }^{54}$ Fleck, "Crisis of 'Reality'," 54.

55 Fleck, "Problem of Epistemology," 103, 86.

${ }^{56}$ Ludwik Fleck, "Zur Frage der Grundlagen der medizinischen Erkenntnis," Klinische Wochenschrift 14 (1935): 1255-59, translated in Thaddeus J. Trenn, "Ludwik Fleck's 'On the Question of the Foundation of Medical Knowledge', Journal of Medicine and Philosophy 6 (1981): 237-56.

57 Ludwik Fleck, "Problems of the Science of Science [1946]," in Cohen and Schnelle, Cognition and Fact, 113-28, on 120. For a popular rendering of the Buchenwald anti-typhus vaccine experiments, see Allen, Fantastic Laboratory of Dr. Weigl, 232-60.
} 
Second World War convinced him that one had to find ways to "immunize the masses against absolute propaganda" and "counteract fanaticism, this number one enemy of mankind," both problems that a sociology of cognition, such as his, could address. ${ }^{58}$ Third, he lamented the erosion of science's "cultural mission," its community-building dimension, as a result of science becoming "a servant of politics and industry" during the Cold War. ${ }^{59}$ Because the operation of science was dependent upon "the entire store of knowledge, experience, and the traditional mental customs of the scientific collective," it was imperative in his view to communicate those foundations over and over, primarily through various levels of science education, from specialist training to popularizations suited for the general public. ${ }^{60}$

\section{Schutz: The Responsibility of the Well-Informed Citizen}

Whereas Fleck's sociology of knowledge from the mid-1930s purposefully examined the role of science education in knowledge construction and in establishing trust in science and its results, Schutz in the 1930s only fleetingly mentioned science, and by implication, science education. In two essays from 1943 and 1946, however, Schutz's focus shifted from the general characteristics of the social world to the role of rationality and science in the public sphere, pivoting from a general phenomenological sociology to the sociology of knowledge. In the process he introduced one of his most important ideal types, the well-informed citizen who was capable of bridging expert knowledge and the layperson's understanding of science. ${ }^{61}$

One does not have to look too deeply for why he turned to the sociology of knowledge. By the time of his December 1946 essay on the well-informed citizen, the atomic bomb and its consequences had deeply affected Schutz. His biographer has noted that among Schutz's papers are clippings on the atomic bomb, most expressing dismay, including reports on the victims of Hiroshima and Nagasaki and anti-nuclear statements by Albert Einstein, Winston Churchill, and the Vatican. On August 9, 1945, the date the second bomb was dropped on Nagasaki, Schutz wrote to his mother that "the world is becoming ever more horrible, unable to be understood, and evil. The atom bomb should call for less inspiration and more doubt." ${ }^{2}$ He was struck by the paradox that those who participated in the construction of the bomb felt guilt, but were honored by governments. ${ }^{63}$ Finally, by July 1946, less than a year after the bombing of Hiroshima and Nagasaki, the United States conducted what could only be called

\footnotetext{
58 Fleck, “To Look," 147, 151.

59 Ludwik Fleck, "Science and Human Welfare [1960]," in Cohen and Schnelle, Cognition and Fact, 153-58.

${ }^{60}$ Fleck, “To Look," 147.

${ }^{61}$ Schutz, "Problem of Rationality;" and Schutz, "Well-Informed Citizen."

62 Barber, Participatory Citizen, 140-41, on 141.

${ }^{63}$ Ibid., 211.
} 
a public atomic spectacle, replete with photographers and artists, on the Bikini Atoll in the Marshall Islands. On that occasion, the two tests of Operation Crossroads, Able and Baker, demonstrated the power of the bomb once again, this time not in war but in striking visual images, many in color, that were circulated globally. ${ }^{64}$

Schutz's sociology of knowledge drew upon his critique of Weberian sociology from 1932, specifically on how meaning was constructed in social action, as the original German title indicated. ${ }^{65}$ Three elements of that critique carried over to his sociology of knowledge: the definition of the social world, how meaning was constructed, and what was meant by an ideal type. First, he defined the social world, or the life-world, as the immediate world of everyday experience, or the world we take for granted. It is pre-scientific and separate from the scientific world, but in and of itself divided into layers sustained by channels of communication. Second, the reality of the social world — or more specifically, the layers in it—is the province of meaning. Schutz identified the uncovering of meaning (Sinn) as the central problem of interpretive sociology. ${ }^{66}$ Like Fleck's "facts," "meaning" in Schutz's social world did not pre-exist, but came into being through different kinds of communication: with our predecessors through received customs, tradition, and above all through history and learning; with our contemporaries through general communication; with associates through the sharing of more specialized experiences and concepts; and with our successors, with whom we communicate through cultural artifacts. ${ }^{67}$ Third, for Schutz as for Weber, the principal tool for interpreting the social world was the ideal type, to which Schutz added a supplementary concept, "typifications," the maxims, recipes, cookbook knowledge, and practical know-how that assisted in understanding social action. ${ }^{68}$

Finally, while education was not one of Schutz's central concerns in 1932, he did acknowledge at the time that education conveyed the contexts of meaning and contributed to the cohesion of specialized groups. Geologists, for instance, automatically recognized the significance of formations in the earth. Likewise, esoteric terms from logic would be meaningless to ordinary people, but not to logicians. In both of these cases the meaning of a sign was learned from "a teacher or book." Education thus provided the conceptual tools for creating other layers of the

${ }^{64}$ United States Joint Task Force One, Operation Crossroads: The Official Pictorial Record (New York: William H. Wise \& Co., 1946). On the artists, see U.S. Navy, "Operation Crossroads: Bikini Atoll," https://www.history.navy.mil/our-collections/art/exhibits/conflicts-and-operations/operationcrossroads-bikini-atoll.html, accessed November 14, 2020.

${ }^{65}$ Der sinnhafte Aufbau der sozialen Welt: Eine Einleitung in die verstehende Soziologie translates as "The Meaningful Construction of the Social World: An Introduction to Interpretive Sociology."

${ }^{66}$ Schutz, Phenomenology of the Social World, 6.

${ }^{67}$ Ibid., 142-43, 207-9, 211-14.

${ }^{68}$ Ibid., 186. Later he explained that the multiplication of typifications aided mastery and prediction, and so was a manifestation of the historical (Weberian) process of rationalization. Schutz, "Problem of Rationality," 135. 
social world, including the layers where specialists and experts reigned. Furthermore, education strengthened meaning in the life-world of the everyday by teaching what was implied but not said. A word like "civilization" had a specific dictionary definition, but "civilization" meant something more to a person in France, where the word carried specific cultural connotations. Schutz identified those connotations as an "aura," which was learned from one's predecessors, tradition, and education. ${ }^{69}$ Already with these few references to education in 1932, Schutz moved away from Weber's distinction between fact and value through his admission that learning was not entirely objective, but was also subjective when it transmitted emotive components such as an "aura."

That departure from Weber became crucial in 1946 when Schutz addressed the sociology of knowledge in the aftermath of the atomic bomb. In Schutz's view, technologies threatened the viability of the social world, for they fractured relationships and anonymized it by disrupting communication and the flow of information that otherwise held layers of social reality intact through shared meanings. The radio, the telephone, air travel and other modern inventions enabled "our own social situation [to be] within the reach of everyone, everywhere." The vulnerability of layers of the social world to these disruptions Schutz found troublesome because "an anonymous other, whose goals are unknown to us because of his anonymity, may bring us together with our system of interests and relevances within his control." That meant a loss of agency, the weakening of control over layers of social reality, and as a consequence, a loss of cohesiveness in those layers; for "we [become] less and less masters in our own right to define what is, and what is not, relevant to us." The atomic bomb, in his view, intensified these pernicious developments because "very soon every place in this world will be the potential target of destructive weapons released to any other place."70

Schutz's answer to the problem of the fraying of the social world began with a rejection of existing forms of the sociology of knowledge because they were overly concerned with truth and "its dependence on social, and especially, economic conditions." He introduced instead a framework that took as its subject matter the social distribution of knowledge and "the mechanism of this distribution." ${ }^{\prime 1}$ How did knowledge flow through society? Here he isolated a process not unlike the dynamic exchanges between Fleck's esoteric and exoteric circles with communications between specialists, laypersons, and popularizers. Through the construction of three ideal types - the man in the street (layperson), expert, and the well-informed citizenSchutz made it clear that his focus was on who, in the social world, was responsible for assessing

${ }^{69}$ Schutz, Phenomenology of the Social World, 118, 121-22, 124-26, 129.

${ }^{70}$ Schutz, "Well-Informed Citizen," 473.

${ }^{71}$ Ibid., 464, 466. 
the trustworthiness of knowledge. ${ }^{72}$ Neither the man on the street nor the expert could assume that role. The man in the street lived "naively in his own and his in-group's intrinsic relevances," had a limited horizon, and relied on typifications and other ways of doing things that were not necessarily completely understood, but that led to practical results. The expert, by contrast, had limited but clear and distinct knowledge, and while at home "in a system of relevances" that was closed to outsiders, did not participate in "the determination of ends," that is, did not engage in the question of how expert knowledge would be used outside a particular field of endeavor. Schutz's expert was thus Weber's. ${ }^{73}$ Instead, Schutz assigned to the well-informed citizen the strategic task of making assessments about knowledge originating in the realm of expertise but having consequences for everyone else. Select individuals in a society had an obligation to take on this role, acting as mediators between experts and laypersons. This well-informed citizen took on the responsibility to be informed in a way that could lead to "reasonably founded opinions" about issues that "are at least mediately of concern." That meant that the wellinformed citizen had to decide what was relevant while gathering "as much knowledge as possible." The trustworthiness of knowledge was the well-informed citizen's ultimate and most socially relevant determination: "it is the well-informed citizen who considers himself perfectly qualified to decide who is a competent expert and even to make up his mind after having listened to opposing expert opinions." ${ }^{34}$

Schutz's assumption here, of course, was that the well-informed citizen had to be educated, but in ways different from the expert or the layperson. Certainly, like the layperson, the wellinformed citizen possessed personal knowledge as well as "the knowledge acquired by othersour teachers and predecessors - and handed down to us as a preorganized stock of problems with the means for their solution." In a similar fashion, the well-informed citizen had to be familiar with the work of experts, but also in a way that recognized the practical implications of expert knowledge claims. The type of education implied in Schutz's analysis went beyond the walls of the classroom to incorporate venues of learning in the public sphere. The well-informed citizen processed what Schutz called socially derived knowledge: knowledge that came either from the experience of another individual or from those who processed knowledge, such as analysts or commentators who could be trusted only if they provided the means to understand clearly and precisely how and why there were differences of opinion on an issue. The goal of that processing, however, was to create socially approved knowledge, knowledge that had been deliberated and that could be trusted for decision-making purposes. That trust also extended to

72 This tripartite division of knowledge-holders echoed a schema Schutz developed in 1943 for understanding rationality in the social world when, with respect to knowledge about a city, he explained the differences between the native, the visitor, and the cartographer. For each, the same object, the city, appeared differently: each exemplified a different level of interpretation, a different set of concepts, and a different level of trust in their knowledge. Schutz, "Problem of Rationality."

73 Schutz, "Well-Informed Citizen," 465, 467-68, 472-74.

${ }^{74}$ Ibid., 466, 474. 
the well-informed citizen who made a claim. Ultimately, socially approved knowledge became knowledge that could be taken for granted by the public, but Schutz warned that it was not to be identified with public opinion as understood in the 1940s. The mere taking of polls, interviews, and questionnaires ignored engagement with knowledge and reflection on it. That kind of "public opinion" was not informed, and hence could not be imposed on those who were better informed. ${ }^{75}$

The political implications of well-informed citizens were clear: they were citizens first, members of a polity active in the exchange of information and in deliberations concerning the valueorientation of knowledge in a public sphere corrupted by crass forms of public opinion. "It is the duty and the privilege of the well-informed citizen in a democratic society," Schutz concluded, "to make his private opinion prevail over the public opinion of the man on the street." ${ }^{76}$ Schutz implied that there was an obligation, for at least some citizens, to become well-informed, and that the way to being well-informed involved not only formal modes of instruction, but also learning from intelligent quarters of the public sphere. In effect he was saying that science education-and, given his concern about technologies that disrupted the social world, it was primarily science education he implicitly invoked—can and should impact the social distribution of knowledge in ways that circumscribed superficial forms of public opinion in favor of a more intelligent system of checks and balances on potentially disruptive forms of knowledge. The well-informed citizen had to make decisions about what was relevant and had to make informed choices, and so was concerned about ends. Schutz thus broke away from Weber by demonstrating the futility and danger of separating fact and value, or even science and politics. Schutz's turn to the sociology of knowledge, which invoked a particular conception of science education, was thus an attempt to foster communication and meaning in the social world in a way that would promote trust in science and its results.

\section{Conclusion}

The purpose of this essay has been to demonstrate how in their ground-breaking works of the 1930s and in essays that followed them, Fleck and Schutz were led to consider the cultivation of trust in science as the responsibility of science education broadly conceived. To accomplish this goal, each focused less on the content of knowledge than on the necessity for various forms of scientific knowledge to circulate among groups ranging from specialists and experts to well-informed citizens and laypersons. Although the interwar years are not a particularly popular focus for historians of science these days, a return to this period, an era of incipient totalitarianism in the midst of intellectual turmoil, speaks to present concerns.

\footnotetext{
75 Ibid., 464-65, 477-78.

${ }^{76}$ Ibid., 478.
} 
There are two lessons from the 1930s for the present. The first is historiographical. What is the goal of studying the history of science education? John L. Rudolph has divided historians of science education into two broad camps: (1) those who are concerned with the role of science education in generational reproduction or the nurturing of professional scientists; and (2) those who deal with problems at the boundary between science and the public, including how habits of mind, moral orders, and values are mediated and negotiated at that boundary as illustrations of the "diverse ways that science education functions in society." 77 In a later article he and Shusaku Horibe asked: how can science education foster civic engagement? One way to promote engagement, they argued, was by educating the public in scientific epistemology: how scientists know what they know. A public thus equipped could assess what scientific results and which scientists could be relied upon. ${ }^{78}$ Rudolph, again, singled out the teaching of reliable knowledge, or knowledge that works, as the civic and moral duty to instill trust in science. ${ }^{79}$ This essay's comparative examination of the work of Fleck and Schutz suggests that in addition to the content of science, or how it is taught, historians would do well to examine, via the routes of informal and formal manifestations of science education, dynamic exchanges between center and periphery, between esoteric and exoteric circles, and between experts and laity, in order to understand the social foundations of the epistemological checks and balances that promote public trust in science and its results.

The coronavirus catastrophe in the United States might be a good place to start. That crisis offers an opportunity to explore the second lesson from the 1930s, a political one. The widespread circulation of disinformation by the Trump administration, coupled with the public's general failure to temper or censor it, offer a fitting case study for investigating the failure of science

\footnotetext{
77 John L. Rudolph, "Science Education: History at the Edge," Studies in History and Philosophy of Biological and Biomedical Sciences 30 (2011): 270-73; John L. Rudolph, "Historical Writing on Science Education: A View of the Landscape," Studies in Science Education 44, no. 1 (2008): 63-82, on 78.

78 John L. Rudolph and Shusaku Horibe, "What do We Mean by Science Education for Civic Engagement?" Journal for Research on Science Teaching 53 (2016): 805-20, esp. 816.

${ }^{79}$ On the civic and moral duty to instill trust in science through the teaching of reliable knowledge, or knowledge that works, see John L. Rudolph, "The Lost Moral Purpose of Science Education," Science Education 104, no. 5 (2020): 895-906.
} 
education, in all of its forms, to serve the public as Fleck and Schutz intended. ${ }^{80}$ That catastrophe led to unprecedented political statements, including by two leading scientific journals, Scientific American and the New England Journal of Medicine, in an effort to restore trust in science. ${ }^{81}$ Some commentators have pointed to a possible political advantage of leaders, such as Angela Merkel, who are trained in science, in shepherding their countries through the pandemic. ${ }^{82}$ The answer need not be, though, to move scientifically-trained political leadership into the esoteric circle where experts reside, but something that engages the public, as Fleck and Schutz have suggested. Naomi Oreskes has called for a new social compact with science, one different from the postwar compact with its emphasis on the alignment of science and the nation-state. Taking a lesson from Fleck and Schutz, that compact might well center on the moral and political necessity of creating an educated citizenry capable of assessing scientific elites, judging scientific results, and speaking truth to power about science and scientific results. ${ }^{83}$ Perhaps children, who during the pandemic have transformed themselves into well-informed citizens at the outermost edge of the exoteric circle, will take the lead. ${ }^{84}$

80 There are hundreds of articles about how the Trump administration has damaged the reputation of science, including: Jeff Tollefson, "How Trump Damaged Science," Nature 586 (2020): 190-94; Joel Achenbach and Laurie McGinley, "Another Casualty of 2020: Trust in Science," The Washington Post, October 12, 2020, https:/www.washingtonpost.com/health/covid-trust-in-science/2020/10/11/ b6048c14-03e1-11eb-a2db-417cddf4816a_story.html, accessed October 12, 2020; Herbert Lin and Harold Trinkunas, "The COVID-19 Infodemic: What Can Be Done About the Infectious Spread of Misinformation and Disinformation," Bulletin of the Atomic Scientists, September 10, 2020, https:// thebulletin.org/2020/09/the-covid-19-infodemic-what-can-be-done-about-the-infectious-spread-ofmisinformation-and-disinformation/, accessed September 10, 2020. Vladimir Putin has stoked the infodemic against American science for years. William Broad, "Putin's Long War against American Science," The New York Times, April 13, 2020, https://www.nytimes.com/2020/04/13/science/putinrussia-disinformation-health-coronavirus.html, accessed April 13, 2020.

${ }^{81}$ H. Holden Thorp, “Trump Lied About Science," Science, September 18, 2020, https://science. sciencemag.org/content/369/6510/1409.full, accessed September 18, 2020; The Editors, "Scientific American Endorses Joe Biden," Scientific American, October 1, 2020, https://www.scientificamerican. com/article/scientific-american-endorses-joe-biden1/, accessed October 1, 2020; The Editors, "Dying in a Leadership Vacuum," New England Journal of Medicine 383, no. 15 (2020): 1479-80.

82 Saskia Miller, "The Secret to Germany's COVID-19 Success: Angela Merkel is a Scientist," The Atlantic, April 20, 2020, https://www.theatlantic.com/international/archive/2020/04/angela-merkelgermany-coronavirus-pandemic/610225/, accessed April 22, 2020.

${ }^{83}$ Naomi Oreskes, "America’s Devastating Divorce from Science," CNN, September 15, 2020, https:// www.cnn.com/2020/09/14/opinions/another-day-another-trump-outrage-on-climate-and-scienceoreskes/index.html, accessed September 15, 2020. Also see more generally: Naomi Oreskes, Why Trust Science? (Princeton and Oxford: Princeton University Press, 2019).

${ }^{84}$ Matt Field, "Students on Lockdown Create a Global Guide to Coronavirus, Conspiracy Theories, Fake Cures, and Other Whopping Lies," Bulletin of the Atomic Scientists, May 26, 2020, https://thebulletin. org/2020/05/students-on-lockdown-create-a-global-guide-to-coronavirus-conspiracy-theories-fakecures-and-other-whopping-lies/, accessed May 26, 2020. 


\section{Acknowledgements}

The author expresses heartfelt gratitude to Ana Simóes and Antonio Sánchez Martínez for their encouragement and support, and thanks Graham Mooney for generously providing copies of articles in Klinische Wochenschrift.

\section{Competing interests}

The author has declared that no competing interests exist. 